\title{
The King and His Retainers Some Notes on Interpolations in the Flateyjarbók Version of Óláfs saga Tryggvasonar en mesta
}

\section{Introduction}

Óláfr Tryggvason — king of Norway from about 995 to 999 or 1000 features prominently in Old Norse historiography and saga literature, where he is presented as an advocate for Christianisation, mainly in Iceland and Norway, and as the king who is tricked into the battle of Svolðr by a coalition of his enemies. The exact location of the battle is difficult to establish; some locate it in the Öresund, others on the Baltic coast of the territories of the Polabian Slavs. ${ }^{1}$ Óláfr Tryggvason dies in this battle. The in part quite detailed accounts of Óláfr's life in these texts, written long after his death, may be surprising, given the fact that there are remarkably few sources about Óláfr that can be deemed contemporary. ${ }^{2}$ The late medieval stage of the development

${ }^{1}$ For a summary of different theories and evidence see e.g. J. Morawiec, P. UrbańCZYK: Building the Legend of the Battle of Svoldr. "Scandinavian Journal of History" 2012, Vol. 37/3, pp. $280-283$.

2 These sources include coins, the Anglo-Saxon Chronicle, and Skaldic poems by Hallfreðr vandræðaskáld Óttarsson; L. LönnRoth: Studier i Olaf Tryggvasons saga. "Samlaren” 1963, Vol. 84, pp. 54, 57; C. KRAG: Óláfr Tryggvason \$1: Historisches. In: Reallexikon der germanischen Altertumskunde. Vol. 22. Eds. H. BeCK et al. Berlin-New York 2003, p. 64; A. BugGe: Sandhed og digt om Olav Tryggvason. "Aarbøger for nordisk Oldkyndighed og Historie" 1910, Vol. 10, pp. 2, 10-11, 13; JóN VIĐAR Sigurðsson: Óláfr Tryggvason. In: Medieval Scandinavia. An Encyclopedia. Eds. P. Pulsiano, K. Wolf. London-New York 1993, p. 446. 
of texts on Óláfr Tryggvason is represented by the so-called Óláfs saga Tryggvasonar en mesta (henceforth ÓTm), which can be translated as "the longest saga of Óláfr Tryggvason." This title adequately describes its comprehensiveness, which markedly contrasts with earlier texts about Óláfr Tryggvason. Starting with chapters on Óláfr's ancestors, ÓTm narrates Óláfr's life, his zeal as king-missionary, his survival of the battle of Svǫlðr, and his death in a monastery some decades after the battle. Into ÓTm, shorter narratives and material from sagas such as Foreyinga saga and Hallfreðar saga vandrceðaskálds were interpolated, ${ }^{3}$ and thus one finds the royal biography embedded in a panorama of the decades around the year 1000 in Norway and the North Atlantic territories with a special focus on the conversion to Christianity. ${ }^{4}$ It is this saga and in particular one of its versions preserved in the manuscript Flateyjarbók (dated to shortly before 1400) - that will be dealt with in this article.

Flateyjarbók is the name used for a manuscript with the shelf mark GKS 1005 fol. at the Árni Magnússon Institute for Icelandic Studies in Reykjavík, Iceland. The name means "the book of Flatey" and is derived from the island where the manuscript was once kept. Flateyjarbók is one of the most outstanding medieval Icelandic codices. It is the largest manuscript of its kind (as regards both size and quantity of folios), and the only one that includes information on who owned and who wrote it. Moreover, the high quality of both its script and illuminations is acknowledged. The praise Flateyjarbók has received as a work of art contrasts with the, in general, meagre attention the manuscript's composition and the texts it contains have attracted. This is also true of ÓTm. For a long time, it stood in the shadow of earlier sagas about Óláfr Tryggvason, due not least to commonly held opinions on the lesser value of late medieval literature. Sigurður Nordal, for example, saw "en haarrejsende mishandling" — "a hair-raising mistreatment" - of Snorri Sturluson's work as interpolations transformed the late medieval versions of the sagas about Óláfr Tryggvason and Saint Óláfr into "uformelige konglomerater" - "unformed conglomerations." Although ÓTm has received little acclaim as a work in its own right, it has frequently been noted that a number of texts or text versions would not have come down to us had they not been preserved as part of it. Examples are Eindriða páttr ilbreiðs and, in the Flateyjarbók version, Porsteins páttr uxafóts and Groenlendinga saga. ${ }^{6}$

${ }^{3}$ Ólafur Halldórsson: Óláfs saga Tryggvasonar. In: Medieval Scandinavia..., p. 449.

${ }^{4}$ See E.B. Heans-GŁogowska: Re-writing History in Fourteenth-century Iceland: Óláfs saga Tryggvasonar en mesta. PhD thesis, University of Cambridge 2014, pp. 65-122, for a discussion of the "national conversion narratives" in ÓTm with particular attention to Iceland.

5 S. Nordal: Sagalitteraturen. In: Litteraturhistorie B: Norge og Island. Ed. S. Nordal. Stockholm 1953, p. 267. Unless stated otherwise, all the translations are by the author of the present article.

${ }^{6}$ Ólafur Halldórsson: Lidt om kilderne til den store saga om Olav Tryggvason. In: Arsberetning 1987-1989. Ed. Selskab for nordisk filologi. København 1990, p. 53; KoLBRÚN Haraldsdóttir: Flateyjarbók. In: Medieval Scandinavia..., p. 198. 
Consequently, an analysis of these texts that are preserved as part of ÓTm should also pay attention to how they interact with other parts of it.

One of the core tasks in philology is the analysis and comparison of different textual variants, whereby any differences have to be seen in relation to how they modify the text as a whole. This article concentrates on the interpolations in the Flateyjarbók version of ÓTm that deal with those retainers of Óláfr Tryggvason who fight with him at the decisive battle of Svǫlðr. These interpolations are some of the most characteristic features of the Flateyjarbók version of ÓTm.

\section{Earlier Texts about King Óláfr Tryggvason and Their Relationship to ÓTm}

Among the numerous sources of ÓTm, some Icelandic texts about Óláfr Tryggvason composed between c. 1190 and 1230 hold a special position. A monk at the monastery of Dingeyrar in northern Iceland, Oddr Snorrason composed a Latin vita about Óláfr, now lost, presumably about the year 1190 . This vita is preserved in an Icelandic translation, referred to as Oddr's Óláfs saga Tryggvasonar, in three manuscripts dating from the period $1250-1300$, and text from this saga was also included in $\mathrm{OTm}^{7}{ }^{7}$ Another monk at Pingeyrar, Gunnlaugr Leifsson also wrote a vita in Latin about Óláfr (which is likewise lost), some parts of which, in Icelandic translation, can be found in ÓTm, ${ }^{8}$ where Gunnlaugr is also mentioned several times. ${ }^{9}$ In contrast to the case of Oddr, however, we do not have other manuscripts apart from ÓTm that preserve Gunnlaugr's writings about Óláfr Tryggvason. Research has therefore focused especially on Oddr's saga, not the least as the saga's prologue presents Óláfr Tryggvason as the precursor of Saint Óláfr, same as John the Baptist was the precursor of Christ. It has been argued that Oddr's saga shows more resemblance to sagas about saints than sagas about kings, as it includes, for instance, passages that can be classified as accounts of miracles, although Óláfr

7 Ólafur Halldórsson: Óláfs saga Tryggvasonar..., p. 449; Finnur Jónsson: Óláfs saga Tryggvasonar (en meiri). "Aarbøger for nordisk Oldkyndighed og Historie" 1930, Vol. 20, pp. 121, 127-136; Óláfs saga Tryggvasonar en mesta, Vol. 3. Ed. Ólafur Halldórsson. København 2000, pp. 64, 67 (hereinafter ÓTmÓH 2000). Oddr's name is, however, only provided in the younger redaction of $O$ Tm.

${ }^{8}$ Finnur Jónsson: Óláfs saga Tryggvasonar..., p. 125.

9 ÓTmÓH 2000, p. 117. 
Tryggvason was not and has never since been canonised. ${ }^{10}$ His saga is strongly influenced by ecclesiastical and hagiographical literature and also shows numerous parallels to, for instance, legends about Saint Óláfr and other Christian kings such as Edward the Confessor and Charlemagne. ${ }^{11}$

Oddr Snorrason's saga was also used for the saga about Óláfr Tryggvason in Heimskringla. This collection of kings' sagas is usually attributed to Snorri Sturluson, who composed it probably between 1220 and $1230 .{ }^{12}$ Snorri's Óláfs saga Tryggvasonar differs significantly from Oddr's in tone. As Ólafur Halldórsson puts it, "Snorri [...] pruned the diction of all hagiographic characteristics" such as Óláfr's survival of the battle of Svolðr and other episodes that might seem implausible. ${ }^{13}$ Snorri's saga about Óláfr has been identified as the major source for $O T_{m},{ }^{14}$ but due to the use of Oddr's and Gunnlaugr's accounts, such episodes found their way into ÓTm.

${ }^{10}$ SveInBJöRn Rafnsson: Ólafs sögur Tryggvasonar: um gerðir peirra, heimildir og höfunda. Reykjavík 2005, pp. 151-171.

${ }^{11}$ L. Lönnroth: Studier..., pp. 57-88; Haki Antonsson: Salvation and Early Saga Writing in Iceland: Aspects of the Works of the Pingeyrar Monks and their Associates. "Viking and Medieval Scandinavia" 2012, Vol. 8, pp. 95-105. The different positions in research on Oddr's motivation for writing such a saga about Óláfr Tryggvason were examined by J. ZERNACK: Vorläufer und Vollender. Olaf Tryggvason und Olaf der Heilige im Geschichtsdenken des Oddr Snorrason munkr. "Arkiv för nordisk filologi" 1998, Vol. 113, pp. 81-82. Zernack concludes that Oddr seems to have aimed at providing Norway with an independent Christian tradition that could be used to legitimise the priority of a national church over claims by the universal church (J. ZeRnACK: Vorläufer und Vollender..., pp. 90, 92). Haki Antonsson takes a different perspective, concentrating on the aspect of salvation (of secular people), concluding that "[t]he opaqueness of salvation and the problem of identifying sanctity inspired the writing of the first biographies of Óláfr Tryggvason and Yngvars saga viðförla [...]" (HAKI Antonsson: Salvation and Early Saga Writing in Iceland..., pp. 125ff., quote at 129).

12 Snorri Sturluson. Heimskringla. Vol. 1. Transl. by A. Finlay, A. Faulkes. London 2011, pp. vii, ix.

13 Ólafur Halldórsson: Óláfs saga Tryggvasonar..., p. 449. On strategies used by Oddr Snorrason to forestall his audience's disbelief of seemingly implausible events, see C. PHeLPSTEAD: Fantasy and History. The Limits of Plausibility in Oddr Snorrason's Óláfs saga Tryggvasonar. "Saga-Book" 2012, Vol. 36, pp. 27-42. On the accounts of Óláfr's survival in Oddr's saga and ÓTm see E.B. Heans-Glogowska: Re-writing History..., pp. 51—54.

${ }^{14}$ Finnur Jónsson: Óláfs saga Tryggvasonar..., pp. 119ff.; Ólafur Halldórsson: Lidt om kilderne..., pp. 48-49. 


\section{The Manuscripts and Redactions of $O$ Tm}

ÓTm is preserved in Icelandic manuscripts from the second half of the $14^{\text {th }}$ century onwards. In one manuscript (Bergsbók), Bergr Sokkason is credited with the compilation of ÓTm. Bergr Sokkason was abbot at Munkapverá, a monastery in northern Iceland, in the second quarter of the $14^{\text {th }}$ century. ${ }^{15}$ In this section, manuscripts that were written up to about 1400 - i.e. the time when Flateyjarbók was written - will be briefly presented. The oldest manuscript of ÓTm is AM 61 fol., dated to around 1350-1375. ${ }^{16}$ Together with a number of other manuscripts, AM 61 fol. represents the so-called older redaction of ÓTm. The manuscripts of the older redaction include AM 53 fol. and AM 54 fol. which are both dated to about 1375-1400 (and which most likely were written in the same scriptorium), ${ }^{17}$ SKB Perg. fol. no. 1, also known as Bergsbók, dated to about $1400-1425$, and some fragments. ${ }^{18}$ The manuscripts of the older redaction do not differ significantly in their textual organisation. One can, for instance, find a different chapter division but no rearrangement of text passages. Therefore, AM 61 fol. was used as the main text in the edition prepared by Ólafur Halldórsson. ${ }^{19}$

In comparison to the older redaction (also called "A text"), the younger redaction (also called "D text") is characterised by a number of alterations (paraphrases, omissions, interpolations, changed sequence of chapters/text), and the differences between the two major manuscripts of the younger redaction are more pronounced than those between the manuscripts of the older redaction. ${ }^{20}$ But still, "Large segments of the D text are in fact identical with the A text except for normal verbal divergences. Even in the revised parts phrases and

15 Ólafur Halldórsson: Lidt om kilderne..., pp. 47, 55; Ólafur Halldórsson: Óláfs saga Tryggvasonar..., p. 449. Compare also E.B. HeAns-GŁogowska: Re-writing History..., pp. $124-131$.

16 The last three quires of AM 61 fol. include passages from the saga about Saint Óláfr and are dated to the middle of the $15^{\text {th }}$ century; ÓTmÓH 2000, p. XXIII. For a comprehensive description of all manuscripts of the older and younger redaction and their relation to each other, see ÓTmÓH 2000. Dating of all manuscripts in this paragraph according to the overview in Ordbog over det norrøne prosasprog. A Dictionary of Old Norse Prose. Registre. Ed. Den Arnamagnæanske kommission. København 1989, pp. 353-354.

17 ÓTmÓH 2000, p. LXVIII.

18 Among these fragments is AM 325 VIII 2c, e-h 4to, which is a copy of AM 54 fol. but must be older than Bergsbók; ÓTmÓH 2000, pp. CLV-CLXIII.

19 Óláfs saga Tryggvasonar en mesta. Vols 1-2. Ed. Ólafur Halldórsson. København 1958, 1961 (hereinafter ÓTmÓH 1958 and ÓTmÓH 1961).

${ }^{20}$ Finnur Jónsson: Flateyjarbók. "Aarbøger for nordisk Oldkyndighed og Historie" 1927, Vol. 17, pp. 150_-169; ÓTmÓH 2000, pp. CCCX_CCCXXIII. 
whole sentences are regularly to be found unchanged," as Ólafur Halldórsson stresses. ${ }^{21}$ The younger redaction of ÓTm can be found in AM 62 fol., dated to $1350-1380,{ }^{22}$ and in Flateyjarbók. The text of ÓTm in Flateyjarbók was copied from a manuscript closely related to AM 62 fol. Most of the shorter interpolated texts in AM 62 fol. can also be found in Flateyjarbók. ${ }^{23}$

Of the abovementioned manuscripts, AM 61 fol., Bergsbók, and Flateyjarbók not only include a saga about Óláfr Tryggvason, but also one about his famous namesake Saint Óláfr, that is, Óláfr Haraldsson, likewise king of Norway, who died in 1030. AM 62 fol. today only preserves ÓTm, but it is likely that it originally also included a saga about Saint Óláfr. ${ }^{24}$ It has been suggested that the so-called separate Óláfs saga helga by Snorri Sturluson was the model for the compiler of ÓTm "[...] and it is not unlikely that his objective in writing the saga was to honour Óláfr Tryggvason with a saga as long as the one composed by Snorri about Óláfr helgi"25; this can help explain the comprehensiveness of ÓTm.

Due to information contained in Flateyjarbók, it can be established that it was written between 1387 and 1394, as the annals end with an entry for that year. ${ }^{26}$ It originally consisted of 202 leaves; on the verso of the first leaf the information is given that the codex was owned by Jón Hákonarson, a wealthy Icelandic farmer, and written by two priests, Jón Pórðarson and Magnús Pórhallsson; it is assumed that the owner also commissioned the codex. ${ }^{27}$ It is not

${ }^{21}$ ÓTmÓH 2000, p. CCCL. Compare also p. CCCXI

${ }^{22}$ Dating according to ÓTmÓH 2000, p. CIII. According to Ordbog over det norrøne prosasprog..., p. 353 , dated to c. $1375-1400$.

${ }^{23}$ ÓTmÓH 2000, pp. 1-44, 47-66. These texts are Norna-Gests páttr, Helga páttr Dórissonar, Óláfr konungr braut goð Drœnda, Halldórs páttr Snorrasonar, Frá Sigurði byskupi, Sýn Brestis, Frá Gunnlaugi ok Oddi. The younger addition to AM 54 fol., written about 1600, likewise includes most of the shorter interpolated texts in AM 62 fol. (omitting Sýn Brestis and Frá Gunnlaugi ok Oddi but, in contrast to Flateyjarbók, including Tryggva Óláfssonar hefnt; ÓTmÓH 2000, pp. LXXI, CCCXI, CCCXIII, 1-64). It is assumed that both Flateyjarbók and the younger part of AM 54. fol. go back to the same manuscript with text of ÓTm; ÓTmÓH 2000, p. CCLXXXI.

${ }^{24}$ The Saga of King Olaf Tryggvason. AM 62 fol. Ed. Ólafur Halldórsson. København 1993, p. 18.

${ }^{25}$ Text by Snorri Sturluson in Óláfs saga Tryggvasonar en mesta. Ed. Ólafur Halldórsson. London 2001, p. v. See also Ólafur Halldórsson: Lidt om kilderne..., p. 48 and A. HeINRICHS: [Review] Stefanie Würth, Elemente des Erzählens [...]. "alvíssmál” 1993, Vol. 3, pp. 116-120, pp. $116-117$.

${ }^{26}$ ÓTmÓH 2000, pp. CXIII-CXVI; Flateyjarbok: En Samling av norske Konge-Sagaer med indskudte mindre Fortcellinger om Begivenheder $i$ og udenfor Norge samt Annaler. Vols $1-3$. Eds. GuĐbrandur Vigfússon, C.R. Unger. Christiania 1860, 1862, 1868 (hereinafter Flb 1860 and Flb 1868); Flb 1860, p. 28; Flb 1868, p. 583.

${ }_{27}$ ÓTmÓH 2000, pp. CXIII, CXXIII. On 1v; printed in Flb 1860 but not paginated. Different hypotheses exist concerning which texts were originally intended for the manuscript and whether it was probably intended as a present for the Norwegian king Óláfr IV Hákonarson 
known where Flateyjarbók was written, but the scribes Jón and Magnús would have needed access to a large number of manuscripts; Ólafur Halldórsson has estimated that about 40 to 50 manuscripts were used for Flateyjarbók. ${ }^{28}$ The manuscript's "basic framework" 29 is formed by four sagas about the Norwegian kings Óláfr Tryggvason, Óláfr Haraldsson, Sverrir Sigurðarson, and Hákon Hákonarson. ÓTm is preceded by shorter texts such as poems, genealogies, and Eiriks saga víforla, while the saga about Hákon Hákonarson is followed by further material on Óláfr Haraldsson, Grcenlendinga páttr, Helga páttr ok Úlfs, Játvarðar saga helga (about Edward the Confessor), and annals. ${ }^{30}$ Towards the end of the $15^{\text {th }}$ century, a saga about two relatives of Óláfr Haraldsson was included, on King Magnús (his son) and on King Haraldr harðráði Sigurðarson (his half-brother), so that Flateyjarbók now contains 225 leaves. ${ }^{31}$

For establishing the peculiarities of the Flateyjarbók version of ÓTm, a comparison with the other, older extant manuscript of the younger redaction, AM 62 fol., is of key importance. Ólafur Halldórsson assumes that the manuscript of $O T m$ used for Flateyjarbók must have been almost identical with AM 62 fol., and, therefore, alterations in the Flateyjarbók version of ÓTm must be those of Jón bórðarson, who wrote this part of the codex; yet, due to lacunae in AM 62 fol., it is at times impossible to determine whether the differences between the older redaction and the Flateyjarbók version are a result of changes already found in the manuscript of OTm that was used for Flateyjarbók. ${ }^{32}$ It should be kept in mind that the question to what extent

(who died in 1387), an idea that has been explored by ÓLAFur Halldórsson: Grettisfaersla: Safn ritgerða eftir Ólaf Halldórsson gefið út á sjötugsafmceli hans,18. april 1990. Eds. SigurgEIR Steingrímsson et al. Reykjavík 1990, pp. 209-210, 430; J. ZernACK: Hyndlulioð, Flateyjarbók und die Vorgeschichte der Kalmarer Union, "skandinavistik" 1999, Vol. 29, pp. 97, 106-110; E.A. RowE: The Development of Flateyjarbók: Iceland and the Norwegian Dynastic Crisis of 1389. Odense 2005, pp. 24ff., 96, 392. In contrast, Kolbrún Haraldsdóttir has argued that it is likely that "[...] the book was from its conception intended for its commissioner, Jón Hákonarson" (KolBRúN Haraldsdóttir: Für welchen Empfänger wurde die Flateyjarbók ursprünglich konzipiert? "Opuscula" 2010, Vol. 13, p. 53).

${ }_{28}$ ÓTmÓH 2000, p. CXXV.

${ }^{29}$ Kolbrún Haraldsdóttir: Flateyjarbók..., p. 198.

${ }^{30}$ For a visualisation of Flateyjarbók's content, see Zernack's table, structured according to scribe, year, and folio; J. Zernack: Hyndlulioð..., p. 95. For concise information on the different texts in Flateyjarbók, see KolBRún Haraldsdóttir: Innhald og komposisjon i Flateyjarbók. "Nordica Bergensia" 2000, Vol. 23, pp. 99-112.

${ }^{31}$ Because of modifications in the saga about St. Óláfr, O.A. Johnsen and Jón Helgason conclude that Flateyjarbók should originally also include a saga about Magnús; Saga Óláfs konungs hins helga - Den store Saga om Olaf den hellige. Efter Pergament-håndskrift $i$ Kungliga Biblioteket i Stockholm nr 2 4to med Varianter fra andre Håndskrifter. Vol. 2. Eds. O.A. Johnsen, Jón Helgason. Oslo 1941, pp. 1032-1033; this has been questioned by KolBrún Haraldsdóttir: Für welchen Empfänger..., pp. 27-28. See also footnote 86 below.

${ }^{32}$ ÓTmÓH 2000, pp. CCLXXXI, CCCXI. 
the scribe decided on these alterations or simply followed instructions must remain unsolved. ${ }^{33}$

Excerpts from separate sagas in the Flateyjarbók-ÓTm are often regarded as typical of this version without noting possible causes. Ólafur Halldórsson points out that the younger redaction is characterised by "drastiske forkortelser" — "drastic abridgements" — of passages which do not deal with Norway, whereas many interpolations have Norway as their setting or are related to Óláfr Tryggvason. ${ }^{34}$ However, his observations first and foremost concern AM 62 fol. Where the state of preservation of AM 62 fol. permits a comparison, one can note that chapters that in the older redaction are based on Jómsvíkinga saga, Fcereyinga saga, and Hallfreðar saga vandrceðaskálds were often abridged in AM 62 fol., contributing to a stronger focus on Óláfr Tryggvason. If the scribe of the Flateyjarbók-ÓTm wanted to include longer accounts, he was more or less forced to replace the shortened passages with excerpts from the abovementioned sagas. ${ }^{35}$

Another feature that sets the Flateyjarbók-ÓTm apart is the saga's last part. The older redaction also includes chapters on the further political developments in Norway in the report of Óláfr's survival. Starting with Jarl Eiríkr Hákonarson, who is among the winners of the battle of Svǫlðr, the focus is then shifted to the rule of Saint Óláfr (and shortly Haraldr harðráði). In AM 62 fol. chapters on Saint Óláfr were abridged or omitted, and in the Flateyjarbók version the last part was changed even further. ${ }^{36}$ Chapters on Saint Óláfr were omitted and those with a connection to Eiríkr Hákonarson were placed after $O ́ T m$, thus creating a transitional passage to the saga about Saint Óláfr. ${ }^{37}$

33 Ólafur Halldórsson: Grettisfersla..., p. 430; see also E.A. Rowe: The Development..., p. 207.

${ }^{34}$ ÓTmÓH 2000, pp. CCCXV- CCCXVI.

${ }^{35}$ For examples, see ÓTmÓH 2000, pp. CCCXVI, CCCXXff. The by-effects are in part even longer chapters than in the older redaction and in part a shift in focus; see also ÓTmÓH 2000, pp. CCCXI, CCCXIX; A. Krakow: Die Óláfs saga Tryggvasonar der Flateyjarbók. Struktur und Gestaltung einer spätmittelalterlichen Konungasaga. PhD thesis, HumboldtUniversität zu Berlin 2009, pp. 54-61, 80-81, 106-107.

${ }^{36}$ For AM 62 fol., an overview of the chapter rearrangement can be found in ÓTmÓH 2000 , p. CCCXVIII. For the Flateyjarbók version and a discussion of the transitional passage (with different assumptions on where it ends and where Óláfs saga helga sets in) compare S. Würth: Elemente des Erzählens: Die pcettir der Flateyjarbók. Basel 1991, pp. 35-36, 57 and A. Krakow: Die Óláfs saga Tryggvasonar der Flateyjarbók..., pp. 29-30, 97-101. Rowe suggests that chapter 406 of the Flateyjarbók-ÓTm is "the destination of the narrative" (E.A. Rowe: The Development..., p. 184) but elsewhere (e.g. pp. 99, 368) she assumes that ÓTm ends with chapter 449 in the text edition Flb 1860. Rowe does not assume a transitional passage between ÓTm and Óláfs saga helga.

${ }^{37}$ Compare with chapters 258-286 in ÓTmÓH 1961, pp. 297-349. 


\section{Óláfr, His Retainers, and the Battle of Svolðr: Interpolations in the Flateyjarbók Version}

The sea battle of Svǫlðr is the focal point in both redactions of ÓTm. Óláfr, led into a trap by Jarl Sigvaldi, fights with his men against a coalition of the Danish king Sveinn tjúguskegg Haraldsson, the Swedish king Óláfr sœnski Eiríksson, and the Norwegian jarl Eiríkr Hákonarson. Óláfr Tryggvason's defeat at Svǫlðr marks at the same time the end of his rule in Norway. Both the events leading to the battle and the battle itself are accounted for in detail, in the Flateyjarbók version in about 27 pages in the text edition. ${ }^{38}$ Already before that account, one can find a list with the names of Óláfr's retainers on three of his ships, with Ormrinn langi being the biggest of them and the one that is skippered by Óláfr himself. Presenting the names of retainers is one of the conventions of the portrayal of rulers. In the older redaction, the names of 43 retainers on the ships are mentioned..$^{39}$ Of these, the overwhelming majority (32 retainers) are only mentioned in this list, and the others almost exclusively in the chapters on Svǫlðr. ${ }^{40}$ Exceptions are Ulfr rauði, Einarr pambarskelfir Eindriðason, and three relatives of Óláfr (Jósteinn Eiríksson, Porkell dyðrill Eiríksson, and Porkell nefja Loðinsson) who have already been introduced earlier in the saga and who also fight with the king. Considering the importance of the battle of Svǫlðr for Óláfr, it is conspicuous that so few of the fighters have played an active part earlier in the saga. On the other hand, the older redaction speaks in detail about men in Óláfr's service - most prominently the Icelanders Kjartan Óláfsson and Hallfreðr vandræðaskáld Óttarsson, and the Faeroese Sigmundr Brestisson - but these do not participate in the battle.

This discrepancy between retainers participating in the battle and their appearance in other parts of the saga has been smoothed out in the Flateyjarbók version, as will be demonstrated with the help of selected examples. A useful starting point is a comparison of the older redaction's list of Óláfr's men with that in the Flateyjarbók version. ${ }^{41}$ For the older redaction, the text of AM

${ }^{38}$ Chapters $371-387$ in Flb 1860, pp. 469-497.

39 ÓTmÓH 1961, pp. 206-207. In AM 61 fol. only 42 men but one more in the other manuscripts of the older redaction.

${ }^{40}$ Compare with Ólafur Halldórsson's index to ÓTmÓH 2000.

${ }^{41}$ To facilitate understanding, a translation is provided. Apart from the standard dictionaries, I also used the translation by Alison Finlay and Anthony Faulkes in Snorri Sturluson... and follow their indication of the meaning of nautical terms from R. CleAsBy, GuĐbrandur Vigfússon: An Icelandic-English Dictionary. Oxford 1874, http://www.ling.upenn .edu/ kurisuto/germanic/oi_cleasbyvigfusson_about.html [accessed: 19 $9^{\text {th }}$ September 2018]. For the meaning of nautical terms compare also Wörterbuch zur altnordischen Prosaliteratur. Digital. Ed. W. BaetKe. Digital edition eds. H. Fix et al. Greifswald 2006, http://emedien 
61 fol. will be presented. The second manuscript of the younger redaction, AM 62 fol., has a lacuna here. For notable modifications in Flateyjarbók, bold print is used (recte and in italics). In addition, some names, which can also be found in AM 61 fol., have been underlined; this will be explained below.

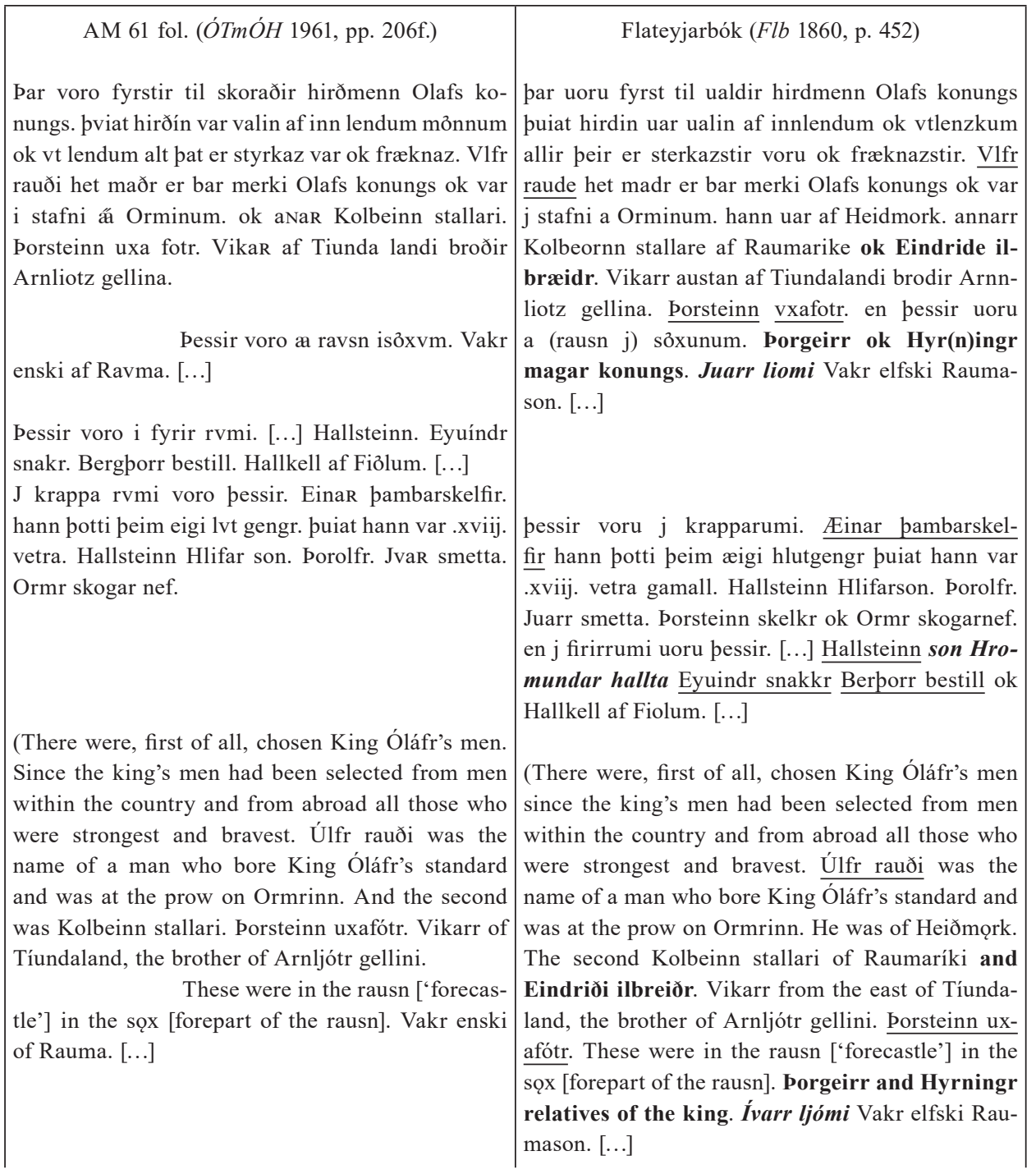

.ub.uni-greifswald.de/ebooks/altnord-wb/baetke_digital.pdf [accessed: $21^{\text {st }}$ October 2017]. For the spelling of proper names, I use the forms provided by Ólafur Halldórsson in the index to ÓTmÓH 2000. My analysis is a summary of A. KRAKOw: Die Óláfs saga Tryggvasonar der Flateyjarbók..., pp. 77-89, 127, 149. 


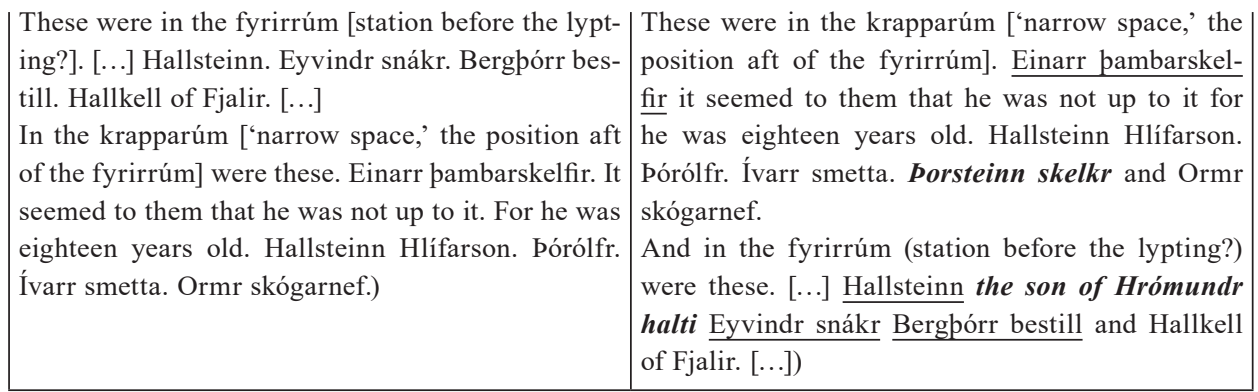

Upright bold print has been used for retainers whose names have been interpolated in the list in Flateyjarbók who, just as in the older redaction, also feature in other parts of ÓTm. In the case of Eindriði ilbreiðr, one can even find a páttr - i.e. an episode or short narrative - about him in ÓTm. Although Eindriði is not mentioned in the list in the older redaction, the páttr ends by mentioning his participation in the battle: ok er pat saugn svmra manna at hann hafui verit með Olafi konungi a Orminum ok fallit par (and that is said by some people that he was with King Óláfr on Ormrinn and fell there).$^{42}$ Instead of this, the Flateyjarbók version has ok skilde alldri Endride vid konung medan peir lifdu badir (and Eindriði never parted from the king as long as they both lived) (lacuna in AM 62 fol.), ${ }^{43}$ and his name was also interpolated in the list of men who died at Svęlðr (lacuna in AM 62 fol..). ${ }^{44}$

Some names have been underlined in the list of men on Ormrinn langi. These retainers are mentioned in the list in both the older redaction and Flateyjarbók, yet in Flateyjarbók one can find further interpolations in which these retainers appear. Particularly illustrative examples are Einarr pambarskelfir, Porsteinn uxafótr, and Hallsteinn (Hrómundarson).

In Flateyjarbók, one can also read about Einarr pambarskelfir in two chapters referred to in research as Halldórs páttr Snorrasonar, a narrative also preserved in AM 62 fol., and in two pættir for which Flateyjarbók is the oldest manuscript, namely Porsteins páttr uxafóts and Orms páttr Stórólfssonar. In Halldórs páttr Snorrasonar, Halldórr kills one of Einarr's men in a rage. ${ }^{45}$ Einarr's verdict in that case — to refrain from having Halldórr killed — is

${ }^{42}$ ÓTmÓH 1961, p. 228.

${ }^{43}$ Flb 1860, p. 464.

${ }^{44}$ Compare ÓTmÓH 1961, p. 285 with Flb 1860, p. 492.

${ }^{4}$ ÓTmÓH 2000, pp. 47-57; Flb 1860, pp. 506-511. Only AM 62 fol. uses the term páttr for this narrative: "Sidasti páttr Olafssaugo Trygguason[ar] Noregs konungs" (ÓTmÓH 2000, p. 47). Due to its links to Haraldr harðráði, the páttr, in a slightly shorter version, can be found a second time in Flateyjarbók; Flb 1868, pp. 428 - 431. On the páttr's structure, protagonists, and biblical motives see J. HARris: Christian Form and Christian Meaning in Halldórs páttr I. In: The Learned and the Lewd. Studies in Chaucer and Medieval Literature. Ed. L.D. BENSON. Cambridge, MA 1974, pp. 249-264. 
motivated by events shortly after the battle of Svolør that are included in the páttr in a retrospective report. Einarr relates how he and two other retainers of Óláfr Tryggvason were captured by Danes after the battle and sold as slaves to a man whose face was hidden under a mask. ${ }^{46}$ This man predicts their future lives and sets them free, requiring of Einarr that he, should an offender ever be in his power, also set this person free. The man briefly lifts his mask before he disappears, and they identify him as Óláfr Tryggvason. Orms páttr Stórólfssonar likewise refers back to the battle of Svǫlðr. In Flateyjarbók, this páttr is placed in the transitional passage to Óláfs saga helga. The Icelander Ormr does not participate in the battle, but a demonstration of Ormr's strength makes it clear to Jarl Eiríkr Hákonarson that king Óláfr's ship Ormrinn langi would never have been taken had Ormr fought by the king's side. ${ }^{47}$ The páttr also includes a chapter in which Ormr manages to bend Einarr pambarskelfir's bow for which he wins Einarr's praise. ${ }^{48}$ In Porsteins páttr uxafóts, a genealogical relation is created between the father of title protagonist borsteinn and two other retainers of King Óláfr, Einarr pambarskelfir and the abovementioned Eindriði ilbreiðr, who both fight with the king at Svolðr. ${ }^{49}$

porsteinn uxafótr as one of Óláfr's men at Svolðr is already mentioned in the sagas by Oddr and Snorri. In ÓTm one can, in addition, also find a short exchange of words between Porsteinn and the king during the battle (lacuna in AM 62 fol.), ${ }^{50}$ but in contrast to the older redaction and AM 62 fol. (which does not have a lacuna here), Porsteinn uxafótr is provided with a biography in the form a páttr. ${ }^{51}$ In this exchange of words between Óláfr and Porsteinn, Alan Binns sees "the point of departure for the páttr, which would then be, like the medieval chivalric enfances, an attempt to provide a past for a hero already known which would agree with the lines of his character already laid down." 52 The páttr relates how İvarr ljómi — the same whose name we find interpolated in the list of retainers in Flateyjarbók ${ }^{53}$ — comes from Norway to Iceland and fathers a son there, borsteinn uxafótr, before he leaves again for Norway. Porsteinn and his Icelandic mother are left behind. The few sources on Porsteinn uxafótr do not indicate that he had Icelandic ancestors. Binns points out that

46 The páttr's narrative of how Einarr was captivated contradicts both the older redaction of ÓTm and Flateyjarbók which relate that Einarr was among the men given quarter by Jarl Eiríkr Hákonarson; e.g. ÓTmÓH 1961, p. 304; Flb 1860, p. 549.

${ }^{47}$ Flb 1860, p. 532.

${ }^{48}$ Flb 1860, p. 532.

${ }^{49} \mathrm{Flb} 1860$, p. 250.

${ }^{50}$ ÓTmÓH 1961, p. 284; Flb 1860, pp. 383, 491. The similarities between this short conversation and the one between Rollant and Oliver in Karlamagnús saga ok kappa hans have been analysed by SveInBJöRn Rafnsson: Ólafs sögur Tryggvasonar..., pp. 237-238.

${ }_{51}$ Flb 1860, pp. 249-263.

52 A. Binns: The Story of Porsteinn Uxafót. "Saga-Book" 1953-1957, Vol. 14, p. 40.

${ }^{53} \mathrm{Flb}$ 1860, p. 452. 
"[n]one of these sources give any reason for believing him to have been an Icelander, and Oddr believed him to have come from southern Norway," and therefore he assumes that the Icelandic descent was ascribed to Porsteinn by the author of the páttr. ${ }^{54}$

In Flateyjarbók, Porsteins páttr uxafóts was inserted in a passage that focuses on the settlement of Iceland. This páttr is not just "a kind of thematic introduction to the account of the conversion of Iceland," as Elizabeth Ashman Rowe has noted, ${ }^{55}$ but even anticipates it, since Porsteinn voluntarily accepts the new faith, as later did the Icelanders on Alping. Porsteinn vows to himself that should he be able to overcome the trollwoman Skjaldvor, he will convert: hafde hann ok heyrt margar saugur ok merkiligar fra Olafui konungi ok peirre tru er hann bodade. hoeitr nu af hreinu hiarta ok hoeilum huga at taka vid peirre tru ok piona Olafi medan hann lifde ef hann kcemizst heill ok lifs j brott af allre kunnattu (He had also heard a lot of noteworthy stories about King Óláfr and the faith he propagated. He promised now with pure heart and sincerely to accept this faith and to serve Óláfr as long as he lived, should he get away with life and limb from all this magic). ${ }^{56}$ Porsteinn succeeds; after this adventure he is acknowledged by his Norwegian father Ívarr ljómi and, having been baptised, becomes one of King Óláfr's retainers. In the chapter on Porsteinn, one can find numerous parallels to Ormr Stórólfsson, ${ }^{57}$ who has already been mentioned above. One example refers to the battle of Svoqlðr, in which Porsteinn uses a sail-yard (beiti-áss) as a weapon. ${ }^{58}$ Ormr also uses a pole (berlings-áss) in the reenactment of a battle scene on Ormrinn langi. ${ }^{59}$ Porsteins páttr uxafóts ends with a reference to Porsteinn's death in the battle of Svǫlðr. ${ }^{60}$ This contradicts other information later, where - as in the older redaction - Dorsteinn is mentioned among the survivors (lacuna in AM 62 fol.. ${ }^{61}$

One of Óláfr's retainers, who in the older redaction is simply named Hallsteinn, is in Flateyjarbók explicitly referred to as the son of Hrómundr halti. Here again, as in the case of Porsteinn uxafótr, a protagonist is provided with a history and an Icelandic descent, because Flateyjarbók also includes an additional, interpolated narrative that finds no equivalent in the older redaction

${ }^{54}$ A. Binns: The Story of..., p. 38.

55 E.A. Rowe: Porsteins páttr uxafóts, Helga páttr Pórissonar, and the Conversion Pattir. "Scandinavian Studies" 2004, Vol. 76/4, p. 460.

${ }^{56} \mathrm{Flb}$ 1860, p. 259. Compare also the English translation in The Tale of Thorstein Bull'sLeg (Dorsteins páttur uxafóts). Transl. by G. Clark. In: The Complete Sagas of Icelanders. Vol. 4. Ed. ViĐAR Hreinsson. Reykjavík 1997, p. 351.

\footnotetext{
57 A. Binns: The Story of..., pp. 50ff.

${ }_{58}$ ÓTmÓH 1961, p. 284; Flb 1860, p. 491.

${ }_{59} \mathrm{Flb} 1860$, p. 531.

${ }^{60} \mathrm{Flb}$ 1860, p. 263.

${ }^{61}$ ÓTmÓH 1961, p. 289; Flb 1860, p. 494.
} 
or AM 62 fol. This interpolation is Hrómundar páttr halta ${ }^{62}$ It is set in Iceland and is about a group of criminal Norwegians who steal some horses that belong to Hrómundr. ${ }^{63}$ In revenge for being found guilty of this crime, twelve Norwegians attack Hrómundr's farm. Hrómundr only has three men to support him; only his son Hallsteinn and a foster-son survive the fight. The páttr ends with the information that Hallsteinn goes to Norway, is converted by King Óláfr Tryggvason, and also becomes one of the king's men; his bravery is noted, and he is said to have fallen on the king's ship at Svǫlðr.

In the longer quotation with the list of Óláfr's men, three names have been put into italics and bold face: Hallsteinn's father Hrómundr halti, Porsteinn skelkr, and Ívarr ljómi. These names do not appear in the older redaction, neither in the list of retainers nor elsewhere. Not only have their names been interpolated into Flateyjarbók, but so too have episodes in which they feature. In addition, Porsteinn skelkr and Ívarr ljómi have also been added to the list of men who were killed in Óláfr's last battle (interpolations in bold print; lacuna in AM 62 fol.):

\begin{tabular}{|c|c|}
\hline $\begin{array}{l}\qquad \text { AM } 61 \text { fol. (ÓTmÓH 1961, p. 285) } \\
\text { par fellv peir bapir bræðr magar konungs. Hyrningr } \\
\text { ok Porgeirr. Vikar af Tíunda landi ok Vlfr hinn } \\
\text { rauði. }\end{array}$ & $\begin{array}{l}\text { Flateyjarbók (Flb 1860, p. 492) } \\
\text { par fellu peir brædr badir magar Olafs Porgæirr ok } \\
\text { Hyrningr Vikarr af Tiundalande Vlfr hinn raude } \\
\text { Endride ilbreidr Porsteinn huiti Porsteinn skelkr } \\
\text { Juar liomi ok margir adrir roskir dreinger [...] }\end{array}$ \\
\hline $\begin{array}{l}\text { (There fell the two brothers relatives of the king. } \\
\text { Hyrningr and borgeirr. Vikarr of Tíundaland and } \\
\text { Úlfr rauði. } \\
\text { and many other brave men [...]). }\end{array}$ & $\begin{array}{l}\text { (There fell the two brothers relatives of Óláfr } \\
\text { Porgeirr and Hyrningr Vikarr of Tíundaland Úlfr } \\
\text { rauði Eindriði ilbreiðr Porsteinn hvíti Porsteinn } \\
\text { skelkr Ívarr ljómi and many other brave men [...]). }\end{array}$ \\
\hline
\end{tabular}

The páttr about Hrómundr halti and the one about Porsteinn skelkr ${ }^{64}$ are placed close together. Both pættir, with their Icelandic protagonists and partly Icelandic settings, occur in a section of ÓTm in which the focus is again on

${ }^{62} \mathrm{Flb}$ 1860, pp. 409-414. A shorter version of it can also be found in the Sturlubók version of Landnámabók, where Hrómundr's son is called Hásteinn, not Hallsteinn, but is likewise said to be among King Óláfr's men on Ormrinn langi; J. de VRIES: Altnordische Literaturgeschichte. Vol. 2. $2^{\text {nd }}$ edition. Berlin 1967, p. 412.

${ }^{63}$ Described as uikingar och ransmenn (vikings and robbers) and Austmenn (men from the Scandinavian continent, esp. Norse merchants or Norwegians); Flb 1860, pp. 410-411; compare R. Cleasby, GuĐbrandur Vigfússon: An Icelandic-English Dictionary... and Wörterbuch..., ed. W. BAETKE for translations. For an interpretation of the páttr as a reflection of Icelandic-Norwegian (trade) relations in the $14^{\text {th }}$ century, see E.A. RowE: Cultural Paternity in the Flateyjarbók Óláfs saga Tryggvasonar. "alvíssmál” 1998, Vol. 8, p. 16 and E.A. Rowe: The Development..., p. 77.

${ }^{64}$ Flb 1860, pp. 409-414, 416-418. 
Iceland. Porsteins páttr skelks opens with a short genealogical reference, and from the information provided there one can construct a connection between Porsteinn and the ancestors of King Óláfr Haraldsson, and between Porsteinn and Kjartan Óláfsson's wife, which puts the páttr's title hero "in an immediately recognizable context," to quote John Lindow, ${ }^{65}$ and adds to the density of links to other protagonists within ÓTm and to Óláfs saga helga. Dorsteins páttr skelks also ends with the mention of his death on Ormrinn langi. ${ }^{66}$ In contrast to the pættir on Porsteinn uxafótr and Hallsteinn Hrómundarson, Porsteins páttr skelks tells about a notable event when Porsteinn skelkr is with Óláfr Tryggvason. One night, ignoring the king's instruction, Porsteinn leaves the hall on his own and meets the devil who tells him of the agony that the heroes of the mythic-legendary past have to suffer in hell. ${ }^{67}$ Porsteins páttr skelks varies a recurrent theme in OTm, Óláfr Tryggvason's determined fight against the old faith and his saviour-like qualities. Porsteinn can be saved from the devil by the king - in contrast to a man called Piðrandi, whose story is told in the two chapters following Porsteins páttr skelks, in Piðranda páttr ok Pórhalls. ${ }^{68}$ For that reason, Joseph Harris has described Porsteins páttr skelks as "a farcical version of the kind of tragic encounter with evil presented by Diðranda páttr ok Pórhalls." ${ }^{69}$ One night, biðrandi hears a knocking on the door and opens it, despite the warning of Pórhallr. Piðrandi sees nine women dressed in black and nine women dressed in white riding towards him from different directions. The women dressed in white cannot protect him, so he dies shortly after this encounter. Pórhallr interprets this as a sign of the new faith that will come, and in OTm one can then find chapters on the successful Christianisation of Iceland.

The contact with the pre-Christian world also provides the topic for Sorla $p_{a} t_{t r}{ }^{70}$ in which Ívarr ljómi is one of the protagonists. Ívarr has already been introduced before as the father of Porsteinn uxafótr. In Sorla páttr, as in Porsteins páttr uxafóts, we find two heathen groups fighting against each other

${ }^{65}$ J. Lindow: Dorsteins pattr skelks and the Verisimilitude of Supernatural Experience in Saga Literature. In: Structure and Meaning in Old Norse Literature. New Approaches to Textual Analysis and Literary Criticism. Eds. J. Lindow et al. Odense 1986, p. 269.

${ }^{66} \mathrm{Flb} 1860$, p. 418.

${ }^{67}$ This content recalls another páttr in ÓTm in which an old man called Norna-Gestr tells King Óláfr stories about the same heroes, Starkaðr and Sigurðr. On Norna-Gests páttr and parallels to Dorsteins páttr skelks see J. ZERNACK: Gests Erzählungen. Germanische Mythologie und der ordo narrationis in der isländischen Geschichtsschreibung des Spätmittelalters. In: Präsenz des Mythos. Konfigurationen einer Denkform in Mittelalter und Früher Neuzeit. Eds. U. Friedrich, B. Quast. Berlin-New York 2004, pp. $318 \mathrm{ff}$.

${ }^{68}$ Flb 1860, pp. 418-421.

69 J. Harris: Theme and Genre in Some Íslendinga Pcettir. "Scandinavian Studies" 1976, Vol. 48/1, p. 14. Compare also E.A. Rowe: The Development..., p. 71.

${ }^{70}$ Flb 1860, pp. 275-283. 
whose wounds are magically healed. ${ }^{71}$ In Sorla páttr, only a Christian can end this everlasting battle. Sorla páttr, preserved for the first time in Flateyjarbók, draws on a subject known from Germanic tradition; in Snorra Edda, presumably the source for Sorla páttr, the gods do not intervene, nor is the spell broken by a Christian. ${ }^{72}$ As Rowe has pointed out, the subject matter has been adapted in Sorla páttr in such a way that it would fit into ÓTm. ${ }^{73}$ This páttr has been interpolated between two chapters on Óláfr Tryggvason's missionary activities in Norway, and contributes to the presentation of the Christian faith as the superior one.

The interpolations linked to Óláfr's men may be few in number but can tell us more about the compositional principles of the Flateyjarbók version of ÓTm. The modifications are all linked to the battle of Svǫlðr. In four pættir interpolated into the Flateyjarbók-ÓTm - Porsteins páttr uxafóts, Sorla páttr, Hrómundar páttr halta, and Dorsteins páttr skelks — the king's retainers who fight on Ormrinn langi either are the central characters or participate in the action. At the end of three of these pættir - Porsteins páttr uxafóts, Hrómundar páttr halta, and Dorsteins páttr skelks — attention is directed to the protagonists' participation in the battle of Svǫlðr. These references underline the battle's significance and also announce that one will read again about these men in ÓTm. Additionally, Orms páttr Stórólfssonar, which was interpolated into the transitional passage to Óláfs saga helga, refers back to the battle of Svolðr. At the beginning of all of these pættir, the scribe Jón Pórðarson left space for medium-sized initials which are also used for other chapters he deemed important. ${ }^{74}$ By doing so, he made sure that attention would be drawn to them. The pættir in which Porsteinn uxafótr, Ívarr ljómi, Hallsteinn, and Porsteinn skelkr feature significantly contribute to the portrayal of at least some of the men who are with Óláfr at Svǫlðr. These retainers are provided with biographies which, in the case of Ívarr and the two Porsteinns, are also linked to the change in faith under Óláfr's rule. The Flateyjarbók version includes an interpolation which is based on Oddr Snorrason's saga that additionally

${ }^{71}$ In Porsteins páttr uxafóts the wounds heal immediately; compare Flb 1860, p. 255.

72 K. Grimstad: Hjaðningavig. In: Dictionary of the Middle Ages. Vol. 6. Ed. J.R. Strayer. New York 1985, pp. 267-268; E.A. RowE: Sörla páttr: The Literary Adaption of Myth and Legend. "Saga-Book" 2002, Vol. 26, pp. 46-47, 55ff.

73 E.A. Rowe: Sörla páttr..., p. 52.

${ }^{74}$ In his part of Flateyjarbók (ÓTm, transitional passage to Óláfs saga helga, and a large part of Óláfs saga helga), Jón Pórðarson left space for the initials, but they were written by Magnús Pórhallsson. In ÓTm, the largest initials can be found at the beginning of the saga (on 5va; 10 lines high and occupying half of the column) and the chapter on Óláfr Tryggvason's birth (on 9va; 9 lines high and almost occupying half of the column); all other initials are smaller. I use "medium-sized" to denote initials stretching over four to six lines; compare handrit.is, https:/handrit.is/is/manuscript/view/GKS02-1005 [accessed: 19 ${ }^{\text {th }}$ September 2018] and the list of initials in E.A. Rowe: The Development..., pp. 373ff. 
emphasises that Óláfr's retainers are outstanding, capable men: mart var mcellt til uarnnadar at ceigi skyllde koma a drekann bleydimenn ne blmỏsur ok ongum uar ueitt skipit nema nokkurr afburdarmadr vari sem bll dęmi finnazst til er fra Olafi er sagt ok hans kauppu(m) (It was warned a lot that neither cowards nor weaklings should come aboard, and no one was allowed aboard, unless he was an outstanding man, of which there are examples in what is told of Óláfr and his champions) (lacuna in AM 62 fol..) ${ }^{75}$

AM 62 fol. cannot be used for comparison of the modified lists with names in the Flateyjarbók version, yet it is unlikely that Ívarr ljómi and Porsteinn skelkr would be mentioned there or that one would find "son Hromundar hallta" added after Hallsteinn, because Dorsteins páttr uxafóts, Sorla páttr, Hrómundar páttr halta, and Dorsteins páttr skelks are not included in the relevant passages where AM 62 fol. is intact and can be drawn upon for comparison. Moreover, these pættir were not included in the younger last part of AM 54 fol. (c. 1600; see above). Therefore, these interpolations must have been added to the Flateyjarbók version.

\section{A Short Comparison with Other Old Norse Compilations}

It cannot be established with certainty which models may have inspired the alterations in the Flateyjarbók version. The only thing that can be done is to point to traditions and texts with similar characteristics such as the tales of Charlemagne and his men that can also be found in the Old Norse Karlamagnús saga ok kappa hans (oldest manuscript fragments dating from the end of the $13^{\text {th }}$ century). According to Lars Lönnroth, this saga could be the model for the $14^{\text {th }}$-century compilations on Saint Óláfr and Óláfr Tryggvason..$^{76}$ If one draws on Karlamagnús saga for a comparison with significant modifications in the Flateyjarbók version of ÓTm, the focus on a few selected retainers who are linked to the decisive battle is in my opinion an instance where one can see similarities. The importance of the retainers for Charlemagne is even expressed in the saga's title ok kappa hans (and his champions). In several parts of the saga, 12 men are said to belong to Charlemagne's closest circle, but only some of these - such as Rollant - are crucial to the saga's plot and involved

${ }^{75}$ Flb 1860, p. 470; compare also the English translation in The Saga of Olaf Tryggvason. By Oddr Snorrason. Transl. by Th.M. Andersson. Ithaca-London 2003, p. 104. Compare also ÓTmÓH 1961, p. 240.

${ }^{76}$ L. LönnRoth: Studier..., p. 83. 
in the battle of Rúnzival, which marks the turning point in the life of Charlemagne. Susanne Kramarz-Bein has pointed out that one can find examples of a critical evaluation of the king's behaviour towards his men in the Old French sources, whereas the main function of the retainers in Karlamagnús saga ok kappa hans is the glorification of the king. ${ }^{77}$

In Flateyjarbók, the interpolated narratives in which we get to know more about Óláfr Tryggvason's retainers Porsteinn uxafótr, Ívarr ljómi, Hallsteinn Hrómundarson, and Porsteinn skelkr, and the narrative named after Ormr Stórólfsson are called pættir. ${ }^{78}$ Literally, páttr (plural pættir) means "strand," i.e. "part of a rope," but the term has been subject to semantic generalisation to "part of any larger entity" and rubrics combining the term páttr with designation of the subject matter are most frequent in Flateyjarbók. ${ }^{79}$ Lindow stresses Flateyjarbók's special status in this regard as "[t]he rubric páttr is virtually unknown in Morkinskinna [...] and rare in other compilations of konungasögur." 80 In research, the term pættir has been used to refer to "short narratives in Old Norse-Icelandic prose," ${ }^{81}$ which not always overlaps with the usage of the term in the manuscripts. A lot of scholarly effort has been dedicated to the question of whether pættir form a generic category of their own and - if so what thematic and structural features they share..$^{82}$ Although pættir are found in kings' sagas, editors and scholars have often treated them as independent narratives. ${ }^{83}$ On the other hand, Rowe points out that even medieval audiences may have read such pættir out of context if the saga they were embedded in was a long one ${ }^{84}$ One can add that a factor contributing to the impression that pættir could be read without their saga context is that one can find examples

77 S. Kramarz-Bein: Die altnordische Karlsdichtung: Das Beispiel der Karlamagnús saga ok kappa hans. In: Karl der Große in den europäischen Literaturen des Mittelalters. Ed. B. BASTERT. Tübingen 2004, pp. 160-161.

${ }^{78}$ Rubrics, initials, and illuminations by Magnús Pórhallsson; compare the note on 1v printed in Flb 1860.

79 J. Lindow: Old Icelandic páttr: Early Usage and Semantic History. "Scripta Islandica" 1978, Vol. 29, pp. 10, 33-37; compare also S. WÜRTH: Elemente des Erzählens..., pp. 34-37.

${ }^{80}$ J. Lindow: Old Icelandic páttr..., p. 36.

${ }^{81}$ J. Harris: Dcettir. In: Dictionary of the Middle Ages. Vol. 12. Ed. J.R. STrayer. New York 1989, p. 1.

${ }^{82}$ For overviews of research on pættir, see e.g. J. HARris: Pcettir... and, most recently, E.A. RowE: The Long and the Short of it'. In: The Routledge Research Companion to the Medieval Icelandic Sagas. Eds. Ármann Jakobsson, Sverrir Jakobsson. London-New York 2017, pp. 151-163, who has also tried to re-evaluate the corpus. For a discussion of how $20^{\text {th }}$-century text editions have formed the notion of pættir as a saga subgenre as well as a summary of "the history of the pættir," see Ármann Jakobsson: The Life and Death of the Medieval Short Story. "Journal of English and Germanic Philology" 2013, Vol. 112, pp. 257-291.

83 Ármann Jakobsson: The Life and Death of..., p. 259; E.A. Rowe: The Long and the Short of it'..., p. 151.

84 E.A. Rowe: The Long and the Short of it'..., pp. 151, 156. 
where the title heroes (or major protagonists) only appear in the pættir, as is the case with Pidranda páttr ok Pórhalls (both redactions) and Norna-Gests páttr (only in the younger redaction) in ÓTm.

One manuscript that includes numerous shorter narratives is Morkinskinna. Morkinskinna is the name given to GKS 1009 fol. (ca. 1275-1280) as well as to the sagas of Norwegian kings included in this manuscript covering the period from 1030 to $1157 .{ }^{85}$ In Morkinskinna, pættir "are clustered particularly densely" in Magnúss saga góða ok Haralds harðráða. ${ }^{86}$ They often tell of an encounter between an Icelander and King Haraldr harðráði, and serve the more complex characterisation of the king, his virtues and flaws ${ }^{87}$ Inspired by this, Stefanie Würth has analysed the characterisation of Óláfr Tryggvason and Óláfr Haraldsson in the main narrative and the pættir of the respective sagas in Flateyjarbók. ${ }^{88}$ Würth analyses all passages rubricated as pættir in Flateyjarbók, i.e. her corpus also includes passages from other sagas (such as Hallfreðar saga vandrceðaskálds). As for Óláfr Tryggvason, her finding is that there are no discrepancies in his portrayal between the main narrative and the pættir, that he is mainly shown as an advocate of the Christian faith, and that the relationship of the king to the Icelanders is stressed. ${ }^{89}$ Some more observations should be added. Interest in Iceland and Icelanders is not exclusive to the Flateyjarbók version of ÓTm - it is already visible in the older redaction of ÓTm, as the

85 J. Louis-Jensen: Morkinskinna. In: Medieval Scandinavia..., p. 419; K.E. Gade: Morkinskinna. In: Reallexikon der germanischen Altertumskunde. Vol. 20. Eds. H. BecK et al. Berlin-New York 2002, pp. 250-253, 250-251. Morkinskinna has several lacunae and its end is not preserved, but it is assumed that it ended in 1177 with the battle of Ré. It was obviously "intended to fill the gap between Óláfs s. helga and Sverris s.”; K.E. GADE: Morkinskinna..., p. 251.

${ }^{86}$ K.E. GADE: Morkinskinna..., p. 251. In the introduction to their English translation, Theodore Andersson and K.E. Gade mention the model role Morkinskinna could have played for e.g. ÓTm and Flateyjarbók, without elaborating this any further (Morkinskinna. The Earliest Icelandic Chronicle of the Norwegian Kings (1030-1157). Transl. by Th.M. ANDERsson, K.E. GADE. Ithaca-London 2000, p. 83). A manuscript based to a great extent on Morkinskinna is Hulda (AM 66 fol. from the middle of the $14^{\text {th }}$ century), which was most likely in the possession of Jón Hákonarson; J. Louis-Jensen: Den yngre del af Flateyjarbók. In: Afmcelisrit Jóns Helgasonar 30. júni 1969. Eds. JАков Benediktsson et al. Reykjavík 1969, p. 237; ÓTmÓH 2000 , p. CXXV; compare footnote 31 above. Again, it can only remain speculation whether the shorter narratives embedded in Magnúss saga góða ok Haralds harðráða inspired the use of the same technique for the Flateyjarbók-ÓTm.

${ }^{87}$ See e.g. ÁrmanN Jakobsson: Í leit að konungi: konungsmynd islenskra konungasagna. Reykjavík 1997, pp. 255, 273.

88 S. WÜRTH: Elemente des Erzählens..., pp. 113-147, 150-157.

89 S. WÜrTH: Elemente des Erzählens..., pp. 120, 126, 131, 151, 153-154, 156. In his analysis of Rognvalds páttr ok Rauðs, Siân Grønlie argues more generally that "pættir can serve as a means of literary commentary on the saga tradition about Óláfr Tryggvason [...]" (S. GRøNLIE: Dáttr and Saga. The Long and the Short of Óláfr Tryggvason. "Viking and Medieval Scandinavia" 2013, Vol. 9, pp. 20-21, 32-33; quote at 20). 
inclusion of the narrative threads about Kjartan and Hallfreðr, and the chapters on the discovery and settlement of the island and the conversion of its inhabitants show. Würth briefly mentions that the Flateyjarbók version of ÓTm includes "Íslendingabættir" not preserved in other manuscripts of ÓTm, but this is not pursued any further in her argumentation..$^{90}$ The additional emphasis on Icelanders in the Flateyjarbók version is most pronounced in the interpolations that provide Óláfr with Icelanders who fight with him at Svǫlðr. Porsteinn skelkr has been added to the saga, as has Ormr Stórólfsson in the transitional passage. Very conspicuously, Porsteinn uxafótr and Hallsteinn are given an Icelandic descent in the pættir. Whereas one can see a parallel to the pættir in Morkinskinna in the emphasis on Icelanders, a significant difference is that Óláfr Tryggvason only sometimes participates in the action, which indicates that the encounter of king and Icelander, said to be crucial in Morkinskinna, is of less importance.

Another scholar who explicitly refers to Morkinskinna in her discussion of Flateyjarbók is Rowe, who concentrates on interpolated pættir in the part of Flateyjarbók that was written by Jón Pórðarson: “What sets Jón's texts apart from the pcettir of Morkinskinna, in addition to the nature of the personal relationship, is their moral dimension [...]." A1 According to Rowe, "[t]he double theme of religion and the relationship with Iceland" is of special importance in six pættir which are only or for the first time preserved Flateyjarbók: Dorleifs páttr jarlaskálds, Dorsteins páttr uxafóts, Sorla páttr, Hrómundar páttr halta, Dorsteins páttr skelks, and Orms páttr Stórólfssonar. ${ }^{92}$ It should be noted that Rowe also assumes Orms páttr Stórólfssonar to be part of ÓTm, which is not the case. ${ }^{93}$ In five of these six narratives, an Icelander is the main protagonist. She argues that the central element in this relationship between King Óláfr and his men is "cultural paternity," i.e. that a protagonist's natural father is replaced by the king as spiritual father. ${ }^{44}$ Summarising her findings, Rowe describes this relationship as follows:

90 S. WÜrTH: Elemente des Erzählens..., p. 151.

${ }^{91}$ E.A. Rowe: The Development..., pp. 50-54, quote at 53.

92 E.A. Rowe: The Development..., p. 58. These pættir are analysed in E.A. Rowe: Cultural Paternity... and E.A. Rowe: The Development..., pp. 61-68.

${ }^{93}$ The Flateyjarbók version of ÓTm ends with sources references and a prayer-like passage expressing gratitude for Óláfr's religious zest, the last word being "AMEN" (Flb 1860, p. 518). This was common practice in medieval texts, compare R. MCGerR: Medieval Concepts of Literary Closure: Theory and Practice. "Exemplaria" 1989, Vol. 1, pp. 149-179, 162-163. The beginning of the transitional passage to Óláfs saga helga is clearly marked by an initial seven lines high which almost occupies half of the column (on 69rb; compare digitalised images at handrit.is) and in addition, ÓTm is referred to ("sem segir j [...]" — as is said in [...]); Flb 1860, pp. 518, 520. The text edition of Flateyjarbók gives a misleading impression of the length of ÓTm, maintaining it ends on Flb 1860, p. 583.

${ }^{94}$ E.A. Rowe: Cultural Paternity..., pp. 17ff. and E.A. Rowe: The Development..., pp. $78-84$. 
Although they resemble in many ways the paettir already interpolated into Óláfs saga Tryggvasonar en mesta, their function as exempla for King Óláfr requires that they offer a particular picture of the relationship between the Norwegian king and the Icelanders who served him, namely, that the Icelanders loved their king like a father and were ready to die for him. Jón Pórðarson's clerical viewpoint strongly influences the way this relationship is presented. The poettir he adds [...] rewrite the relationship between lord and retainer as a Christian para-familial one in which the Icelandic hirðmenn become the spiritual sons of Óláfr Tryggvason. ${ }^{95}$

For Porsteins páttr uxafóts such an interpretation can claim justification, but for the other pættir it is problematic. Rowe does not include Porleifs páttr jarlaskálds in her discussion of "cultural paternity"; this narrative tells of an Icelander, but he is not one of Óláfr's men. ${ }^{96}$ In Porsteins páttr uxafóts and Sorla páttr the Norwegian Ívarr ljómi is presented as one of Óláfr's retainers, but how he entered the king's service is of no relevance in either of them. For the same reason, Hrómundar páttr halta is not suited to proving that King Óláfr became the spiritual father, because Hallsteinn Hrómundarson's conversion and that he became a retainer are only briefly mentioned at the end of the páttr. ${ }^{97}$ Porsteinn skelkr is arguably saved by the king. Afterwards, he claims to have hoped for the king's help and is also appointed hirðmaðr, ${ }^{98}$ but already in the opening lines of the páttr we are informed that he has been for some time with the king. As regards Ormr Stórólfsson, Rowe herself notices that he "has no need for Óláfr's spiritual aid." 99 For the reasons given, these six pættir can only partially serve as an illustration of the spiritual relationship between the king and his men.

95 E.A. Rowe: The Development..., p. 92.

${ }^{96}$ Compare E.A. Rowe: The Development..., pp. 78-84. Moreover, this páttr might also have been included in AM 62 fol. (a lacuna makes a comparison with Flateyjarbók impossible); ÓTmÓH 2000, pp. LXXXVIII, CCCXXI.

${ }^{97}$ Flb 1860, p. 414.

98 I.e. a king's man; Flb 1860, pp. 417-418.

99 E.A. Rowe: The Development..., p. 87. Furthermore, Rowe assumes that the six pættir form two cycles wherein each páttr corresponds with one in the other cycle (E.A. RowE: $\mathrm{Cul}$ tural Paternity..., pp. 19ff. and E.A. RowE: The Development..., pp. 85-86). She also sees religious significance in the number six (E.A. Rowe: The Development..., pp. 87-88, 138-139, 295). It is, however, problematic to assume the addition of six pættir because, as noted above, Porleifs páttr jarlaskálds might have been included in AM 62 fol. and Orms páttr Stórólfssonar is not part of ÓTm. 


\section{Concluding Remarks}

The focus on the battle of Svǫlðr most obviously sets the Flateyjarbók version apart from the other manuscripts of ÓTm. In the older redaction, only a few retainers who fight with Óláfr at Svǫlðr have been introduced before. Therefore, most of them just remain names and do not call to mind episodes in which they have played a significant role. In the Flateyjarbók version, this discrepancy between the retainers' participation in the battle and their appearance in other parts of the saga has been levelled out by positioning the interpolated pættir (Dorsteins páttr uxafóts, Sorla páttr, Hrómundar páttr halta, Dorsteins páttr skelks) in the narrative block preceding the battle, and by interpolating the names in the list of retainers on Óláfr's ship (Eindriði ilbreiðr, Ívarr ljómi, Porsteinn skelkr, "son Hromundar hallta") as well as the list of retainers who died in the battle (Eindriði ilbreiðr, Ívarr ljómi, Porsteinn skelkr). As has been indicated in the analysis, the four interpolated pættir do not exclusively show intersections with Óláfr's last battle, but also with other subjects taken up in ÓTm. Moreover, one interpolated narrative linked to the battle of Svǫlðr (Orms páttr Stórólfssonar) was placed in the transitional passage to Óláfs saga helga. Taken together, these interpolations contribute to a greater coherence within the saga of Óláfr Tryggvason and to a certain degree also within the manuscript as a whole.

\section{References}

\section{Primary sources, translations, and dictionaries}

Cleasby R., GuĐbrandur Vigfússon: An Icelandic-English Dictionary. Oxford 1874, http://www.ling.upenn.edu/ kurisuto/germanic/oi_cleasbyvigfusson_about.html [accessed: $19^{\text {th }}$ September 2018].

Flateyjarbok: En Samling av norske Konge-Sagaer med indskudte mindre Fortcellinger om Begivenheder i og udenfor Norge samt Annaler. Vols 1-3. Eds. GuĐbrandur Vigfússon, C.R. Unger. Christiania 1860, 1862, 1868.

handrit.is, https://handrit.is/is/manuscript/view/GKS02-1005 [accessed: 19 ${ }^{\text {th }}$ September 2018].

Morkinskinna. The Earliest Icelandic Chronicle of the Norwegian Kings (1030-1157). Transl. by Th.M. Andersson, K.E. GADE. Ithaca-London 2000. 
Óláfs saga Tryggvasonar en mesta. Vols 1-3. Ed. Ólafur Halldórsson. København 1958, 1961, 2000.

Ordbog over det norrøne prosasprog. A Dictionary of Old Norse Prose. Registre. Ed. Den Arnamagnæanske kommission. København 1989.

Saga Óláfs konungs hins helga - Den store Saga om Olaf den hellige. Efter Pergamenthåndskrift $i$ Kungliga Biblioteket i Stockholm $n r 2$ 4to med Varianter fra andre Håndskrifter. Vols 1-2. Eds. O.A. Johnsen, Jón Helgason. Oslo 1941.

Snorri Sturluson. Heimskringla. Vol. 1. Transl. by A. Finlay, A. Faulkes. London 2011.

Text by Snorri Sturluson in Óláfs saga Tryggvasonar en mesta. Ed. Ólafur Halldórsson. London 2001.

The Saga of King Olaf Tryggvason. AM 62 fol. Ed. ÓLAfur Halldórsson. København 1993.

The Saga of Olaf Tryggvason. By Oddr Snorrason. Transl. by Th.M. Andersson. Ithaca-London 2003.

The Tale of Thorstein Bull's-Leg (Porsteins páttur uxafóts). Transl. by G. Clark. In: The Complete Sagas of Icelanders. Vol. 4. Ed. VIĐAR Hreinsson. Reykjavík 1997.

Wörterbuch zur altnordischen Prosaliteratur. Digital. Ed. W. Baetke. Digital edition eds. H. FIX et al. Greifswald 2006, http://emedien.ub.uni-greifswald.de/ebooks/altnord-wb/bae tke_digital.pdf [accessed: $21^{\text {st }}$ October 2017].

\section{Secondary sources}

ÁrmanN Jakobsson: Í leit að konungi: konungsmynd islenskra konungasagna. Reykjavík 1997.

Ármann Jakobsson: The Life and Death of the Medieval Short Story. "Journal of English and Germanic Philology" 2013, Vol. 112.

Binns A.: The Story of Porsteinn Uxafót. "Saga-Book" 1953-1957, Vol. 14.

BugGe A.: Sandhed og digt om Olav Tryggvason. "Aarbøger for nordisk Oldkyndighed og Historie" 1910, Vol. 10.

FInNuR Jónsson: Flateyjarbók. "Aarbøger for nordisk Oldkyndighed og Historie" 1927, Vol. 17.

Finnur Jónsson: Óláfs saga Tryggvasonar (en meiri). "Aarbøger for nordisk Oldkyndighed og Historie" 1930, Vol. 20.

GAdE K.E.: Morkinskinna. In: Reallexikon der germanischen Altertumskunde. Vol. 20. Eds. H. BeCK et al. Berlin-New York 2002.

Grimstad K.: Hjaðningavíg. In: Dictionary of the Middle Ages. Vol. 6. Ed. J.R. Strayer. New York 1985.

Grønlie S.: Páttr and Saga. The Long and the Short of Óláfr Tryggvason. "Viking and Medieval Scandinavia" 2013, Vol. 9.

HaKi Antonsson: Salvation and Early Saga Writing in Iceland: Aspects of the Works of the Pingeyrar Monks and their Associates. "Viking and Medieval Scandinavia" 2012, Vol. 8.

Harris J.: Christian Form and Christian Meaning in Halldórs páttr I. In: The Learned and the Lewd. Studies in Chaucer and Medieval Literature. Ed. L.D. Benson. Cambridge, MA 1974.

Harris J.: Pcettir. In: Dictionary of the Middle Ages. Vol. 12. Ed. J.R. Strayer. New York 1989.

HARris J.: Theme and Genre in Some Íslendinga Pattir. "Scandinavian Studies" 1976, Vol. 48/1. 
Heans-GŁogowska E.B.: Re-writing History in Fourteenth-century Iceland: Óláfs saga Tryggvasonar en mesta. PhD thesis, University of Cambridge 2014.

Heinrichs A.: [Review] Stefanie Würth, Elemente des Erzählens [...]. "alvíssmál" 1993, Vol. 3.

Jón ViĐar Sigurðsson: Óláfr Tryggvason. In: Medieval Scandinavia. An Encyclopedia. Eds. P. Pulsiano, K. Wolf. London-New York 1993.

Kolbrún Haraldsdóttir: Flateyjarbók. In: Medieval Scandinavia. An Encyclopedia. Eds. P. Pulsiano, K. Wolf. London-New York 1993.

KolBRÚN Haraldsdóttir: Für welchen Empfänger wurde die Flateyjarbók ursprünglich konzipiert? "Opuscula" 2010, Vol. 13.

KolBRÚn Haraldsdóttir: Innhald og komposisjon i Flateyjarbók. "Nordica Bergensia” 2000, Vol. 23.

KraG C.: Óláfr Tryggvason \$1: Historisches. In: Reallexikon der germanischen Altertumskunde. Vol. 22. Eds. H. BECK et al. Berlin-New York 2003.

Krakow A.: Die Óláfs saga Tryggvasonar der Flateyjarbók. Struktur und Gestaltung einer spätmittelalterlichen Konungasaga. PhD thesis, Humboldt-Universität zu Berlin 2009.

Kramarz-Bein S.: Die altnordische Karlsdichtung: Das Beispiel der Karlamagnús saga ok kappa hans. In: Karl der Große in den europäischen Literaturen des Mittelalters. Ed. B. BASTERT. Tübingen 2004.

Lindow J.: Old Icelandic páttr: Early Usage and Semantic History. "Scripta Islandica" 1978, Vol. 29.

Lindow J.: Porsteins páttr skelks and the Verisimilitude of Supernatural Experience in Saga Literature. In: Structure and Meaning in Old Norse Literature. New Approaches to Textual Analysis and Literary Criticism. Eds. J. Lindow et al. Odense 1986.

LönnRoth L.: Studier i Olaf Tryggvasons saga. "Samlaren” 1963, Vol. 84.

Louis-Jensen J.: Den yngre del af Flateyjarbók. In: Afmcelisrit Jóns Helgasonar 30. júní 1969. Eds. ЈАков Benediktsson et al. Reykjavík 1969.

Louis-Jensen J.: Morkinskinna. In: Medieval Scandinavia. An Encyclopedia. Eds. P. Pulsiano, K. Wolf. London-New York 1993.

McGerr R.: Medieval Concepts of Literary Closure: Theory and Practice. "Exemplaria" 1989, Vol. 1.

Morawiec J., URBaŃCZYK P.: Building the Legend of the Battle of Svoldr. "Scandinavian Journal of History" 2012, Vol. 37/3.

Nordal S.: Sagalitteraturen. In: Litteraturhistorie B: Norge og Island. Ed. S. Nordal. Stockholm 1953.

Ólafur Halldórsson: Grettisfcersla: Safn ritgerða eftir Ólaf Halldórsson gefið út á sjötugsafmoeli hans,18. apríl 1990. Eds. SigurgeIr Steingrímsson et al. Reykjavík 1990.

Ólafur Halldórsson: Lidt om kilderne til den store saga om Olav Tryggvason. In: Arsberetning 1987-1989. Ed. Selskab for nordisk filologi. København 1990.

Ólafur Halldórsson: Óláfs saga Tryggvasonar. In: Medieval Scandinavia. An Encyclopedia. Eds. P. Pulsiano, K. Wolf. London-New York 1993.

Phelpstead C.: Fantasy and History. The Limits of Plausibility in Oddr Snorrason's Óláfs saga Tryggvasonar. "Saga-Book" 2012, Vol. 36.

Rowe E.A.: Cultural Paternity in the Flateyjarbók Óláfs saga Tryggvasonar. "alvíssmál” 1998, Vol. 8.

Rowe E.A.: Sörla páttr: The Literary Adaption of Myth and Legend. "Saga-Book" 2002, Vol. 26.

Rowe E.A.: The Development of Flateyjarbók: Iceland and the Norwegian Dynastic Crisis of 1389. Odense 2005. 
Rowe E.A.: The Long and the Short of it'. In: The Routledge Research Companion to the Medieval Icelandic Sagas. Eds. Ármann Jakobsson, Sverrir Jakobsson. London-New York 2017.

Rowe E.A.: Porsteins páttr uxafóts, Helga páttr Pórissonar, and the Conversion Pattir. "Scandinavian Studies" 2004, Vol. 76/4.

SveInBJÖRn Rafnsson: Ólafs sögur Tryggvasonar: um gerðir peirra, heimildir og höfunda. Reykjavík 2005.

VRIES J. de: Altnordische Literaturgeschichte. Vol. 2. 2 $2^{\text {nd }}$ edition. Berlin 1967.

WürTH S.: Elemente des Erzählens: Die pattir der Flateyjarbók. Basel 1991.

ZeRnaCK J.: Gests Erzählungen. Germanische Mythologie und der ordo narrationis in der isländischen Geschichtsschreibung des Spätmittelalters. In: Präsenz des Mythos. Konfigurationen einer Denkform in Mittelalter und Früher Neuzeit. Eds. U. FrIEDRICH, B. QUAST. Berlin-New York 2004.

Zernack J.: Hyndlulioð, Flateyjarbók und die Vorgeschichte der Kalmarer Union. "skandinavistik" 1999, Vol. 29.

Zernack J.: Vorläufer und Vollender. Olaf Tryggvason und Olaf der Heilige im Geschichtsdenken des Oddr Snorrason munkr. "Arkiv för nordisk filologi” 1998, Vol. 113.

Annett Krakow

Kilka uwag na temat interpolacji w Óláfs saga Tryggvasonar en mesta we Flateyjarbók

Streszczenie

W artykule badane są interpolacje w Óláfs saga Tryggvasonar en mesta (największej sadze o Olafie Tryggvasonie) w rękopiśmie Flateyjarbók, dotyczące tych mężczyzn w świcie króla Olafa Tryggvasona, którzy z nim walczyli w bitwie morskiej pod Svǫlðr. Najpierw przedstawione są źródła oraz różne redakcje sagi. Punktem wyjścia do analizy jest lista świty Olafa na okręcie królewskim Ormrinn langi w starszej redakcji sagi. Tylko niektórzy z tych mężczyzn pojawiają się również w innych częściach sagi. Modyfikacje we Flateyjarbók obejmują zarówno interpolacje imion w liście świty, jak i dodatkowe opowieści w bloku narracyjnym przed bitwą. W ten sposób modyfikacje intensyfikują koherencję i narracyjną wielowarstwowość w sadze o Olafie Tryggvasonie.

Słowa klucze: Óláfr Tryggvason, literatura staronordycka, pættir, warianty tekstu, obraz władców 


\section{Annett Krakow}

Der König und seine Gefolgsleute. Einige Anmerkungen zu den Interpolationen in der Flateyjarbók-Version der Óláfs saga Tryggvasonar en mesta

\section{Zusammenfassung}

Im Artikel werden die Interpolationen in der Óláfs saga Tryggvasonar en mesta (der größten Saga über Óláfr Tryggvason) in der Handschrift Flateyjarbók untersucht, die jene Männer im Gefolge von König Óláfr Tryggvason betreffen, die mit ihm in der Seeschlacht zu Svǫlðr kämpfen. Zuerst werden die Quellen und die unterschiedlichen Redaktionen der Saga vorgestellt. Den Ausgangspunkt für die Analyse bildet die Liste der Gefolgsleute von Óláfr auf dem königlichen Schiff Ormrinn langi in der älteren Redaktion der Saga. Von diesen Männern treten nur wenige auch in anderen Teilen der Saga auf. Die Modifikationen in der Flateyjarbók umfassen sowohl die Interpolation von Namen in der Liste über die Gefolgsleute als auch zusätzliche Erzählungen im Erzählblock vor der Schlacht. Dadurch intensivieren die Modifikationen die Kohärenz und narrative Vielschichtigkeit in der Saga über Óláfr Tryggvason.

Schlüsselwörter: Óláfr Tryggvason, altnordische Literatur, pættir, Textvarianten, Herrscherbild 